Power in Motion: Tracking Time, Space and Movement in the British Penal Estate

\title{
Abstract:
}

This paper tracks the impact of prison transfers (and mobility considerations more generally) on the spatio-temporal regimes pursued within the British Penal Estate. I argue that what appear from outside as static spaces of detention are in fact nodes within a network deeply crisscrossed by internal patterns of mobility and the problematics of time-space coordination. I explore the power relations that shape prisoner patterns of movement and highlight the distinctive states of deprivation they generate.

Key Words:

Carceral Geography, mobilities, power, prison, hyperincarceration, overcrowding

Luca Follis

Department of Law

Bowland North

Lancaster University

LA1 4YN

I.follis@lancaster.ac.uk

Acknowledgments: Sue Penna and David Smith provided valuable suggestions on earlier drafts of this paper. I would also like to thank the four anonymous reviewers for Society and Space for their stimulating and insightful comments. 


\section{Power in Motion: Tracking Time, Space and Movement in the British Penal Estate}

Introduction

Over the course of 2010 HMP Leeds, a large 'local prison' in the English Midlands, sent 6,777 prisoners to the courts and received 9,460, it transferred to other prisons 1,882 prisoners and received 480; it managed 780 hospital escorts for medical appointments and treatment, as well as initiating 11,411 furloughs for funerals, dying relatives, home leaves or town visits (IMP 2010c, 19). ${ }^{1}$ The scale, complexity and frequency of this movement are not atypical for such an institution. Indeed HMP Leeds represents a single node in an expansive prison network (the British Penal estate) deeply crisscrossed by internal patterns of mobility and the external entry/exit flows of the broader criminal justice system within which it is embedded.

And yet, though the daily 'churn' of admitting, relocating and discharging prisoners is clearly a core facet of everyday penal governance it sits uneasily against the commonsense view

\footnotetext{
${ }^{1} \mathrm{~A}$ furlough is a temporary release from prison for a short duration of time to either respond to an exceptional, personal circumstance (e.g., medical necessity, compassionate grounds, marriage) or a wider criminal justice need (e.g., paid or unpaid work placements, training or education). This practice is formally called Release on Temporary License (ROTL) and under its heading, a broad array of temporary release options are possible (i.e., Resettlement Day Release [RDR], Resettlement Overnight Release [ROR], Childcare Resettlement License [CRL] and Special Purpose License [SPL]) (NOMS 2015).
} 
that prisons are islands of incapacity; totalizing and warehousing institutions (Goffman 1961, Irwin 2005) where prisoners feel the constraint of restricted mobility and the weight of 'dead time' (Johnson 2005: 256). The above tension parallels another commonsense disjuncture, this time scalar: when one thinks of prisons one is more likely to envisage single institutions and not systems or networks of prisons. Further still from everyday view might be the expansive carceral structures that reach beyond these institutions into the community and anchor ongoing practices of criminalization and hyper-incarceration (Wacquant 2001, 2009). Both fallacies occlude key points in understanding contemporary practices of imprisonment and their connection to the broader political economic arrangements they help to shape and sustain (Davis 2003; De Giorgi 2006; Gilmore 2007).

Scholars attentive to the political dimensions of mobility (Creswell 1999, 2006) have emphasized that social acceleration (Rosa 2013) generates new hegemonic practices and subjugated identities (Law 1999; Imrie 2000; Urry 2004; Adey 2004; Neumayer 2006; Gogia 2006; Sager 2006; Franquesa 2011). Within this literature, the de-mobilization of traditionally 'mobile' groups like tramps, gypsies and other 'nomads' (Mitchell 1997; Hetherington 2000; Creswell 2001; Shubin 2011) or the contingent and coerced mobility of migrants and refugees have been analyzed (Kofman 2002; Shuster 2005). Others have complemented the focus on the mobility of groups with the study of state mobility systems drawing important parallels between structures of detention and structures of imprisonment: both produce contradictory formulations and rearrangements of the mobility/containment dynamic (Gill 2009a; Martin and Mitchelson 2009; Moran, Piacentini and Pallot 2011; Mountz et al. 2013). 
For example, Mountz et al. (2013) have noted that emergent detention practices and processes attempt to fix, know and identify incoming migrants as well as to 'seal off' and contain their bodies in remote detention centers. Yet such practices also produce highly mobile identities and bodies, through the erasure of individuality and the application of generalized suspicion or through the transfers and deportations deemed necessary to produce future states of immobility (527-528). Similarly Gill (2009a, 2009b) has noted that the British State deploys strategies of mobility and stillness in the governance of asylum seekers. Transfers and seizures are frequent, sudden and traumatic; they destabilize staff-migrant relations as well as interrupt and motivationally challenge the work of advocacy groups (Gill 2009b). Indeed, in this account geographical, psychological and corporeal stillness becomes the antithesis of 'governmental mobility' and an important source of resistance.

Turning from analyses of detention practices to the academic commentary on imprisonment, space and movement, accounts of the prison's 'revolving door' (Clemmer 1958; Irwin 1980; 1985; Scarce 2002; Crewe 2009) can be contrasted with the enforced seclusion and immobility of prisoners in long-term confinement or supermax prisons (Kurki and Morris 2001; Haney 2003; Rhodes 2004; Mears and Reisig 2006). High recidivism and reoffending rates maintain heavy flows through US state penal institutions even as spatial solutions that prioritize containment seemingly proliferate. At the same time, a focus on the "spatiality of imprisonment" underscores the "necessarily insular and outwardly dependent" (Bonds 2013:1391) nature of prisons and their connection to carceral frameworks and structures (Wacquant 2001, Peck 2003, Martin and Mitchelson 2009). Important themes in these carceral geographies have included: the politics of proximity and distance in prisoner visitations (Moran 
2013a, 2013b), the political economy of criminalization and prison siting (Che 2005; Gilmore 2007; Bonds 2009, 2013), the destructive impact of variable policing strategies, high imprisonment and coercive mobility on urban neighborhoods (Clear et. al. 2003; Clear 2007; Desmond and Valdez 2012) and the emergence of the prison as a "labor market institution" that "shapes the social distribution of work and wages" among increasingly contingent labor forces (Peck and Theodore 2008: 276).

This paper builds on the above insights by focusing on the transportation dynamics that animate one macro-level component of the carceral chain. I hope to illustrate how the tension between stillness and movement, containment and mobility described above is navigated and managed within the British penal context and in its network of institutions. With some notable exceptions (e.g., Martin and Mitchelson 2009; Moran, Piacentini and Pallot 2011) much of the literature on prisoner movement focuses on the many points of intersection between prisons and the outside, but I want to emphasize the importance of mobility and movement within the system itself and throughout the entire spatio-temporal process of incarceration. To do so, I outline the practices through which the British Penal Estate operationalizes prisoner movement and explain what these practices reveal about the functioning of power "in motion".

In the next section, I describe the institutional scaffolding that supports and drives the penal estate's transportation system which is characterized by two countervailing approaches to prisoner transfers (a top-down, instrumental application of prisoner movement pursued alongside and against an embodied, progressive system of prisoner mobility). I argue that taken together, these modalities of movement comprise veritable regimes of circulation. That is, they represent twin mobilizations of the prison system's control apparatus where movement 
becomes a crucial component in the operation and maintenance of penal power. Drawing upon management and organizations research, I then move to the identification of the 'push' and 'pull' factors that have animated and determined the near history of prisoner movement. I focus on the combined impact of estate-wide overcrowding and new sentencing and offender management frameworks introduced by the British state since 2003 to problematize the seemingly self-evident market analogy of supply and demand so frequently championed to justify penal expansionism. ${ }^{2}$ The following section then shifts to the examination of penal flows themselves: it tracks the pattern of prisoner movement engendered by regimes of circulation and highlights some of the distinctive spatio-temporal states of deprivation they generated. Finally, I conclude by showing how the mobility practices I describe are themselves undergoing a process of carceral 'rearrangement' linked to the abolition of IPP sentences and the externalization of some of the very institutional paradoxes identified in this article.

\footnotetext{
${ }^{2}$ The empirical material for this paper draws extensively on the documents, investigations, inspections and reports published by the Ministry of Justice between 2003 and 2013. The most important set of documents analyzed are the inspection reports of Her Majesty's Inspectorate of Prisons (HMIP) and the annual reports of the Independent Monitoring Boards (IMB) of individual prisons. Every prison in the estate is inspected, at a minimum, every five years (but frequently HMIP manages to do this once every 2-3 years). Inspections are in-depth and generate lengthy reports that detail the overall conditions of custody, the range of activities and services provided, the challenges faced by these institutions and the character and needs of their populations. Throughout the period under study, the progression of prisoners under indeterminate sentences, overcrowding and prisoner transport were key areas of comparison among different institutions. In contrast, each prison has an IMB board composed of volunteers (appointed by the Home Office) that monitor the standards of care within their individual prisons. Each year they submit an annual report that documents their observations; often these 'local' documents provide a useful counterpoint to official reports.
} 


\section{Regimes of Circulation}

A traditional view of prisons emphasizes their location 'behind the scenes' of everyday life and their role as containers of violence and power (Elias 1985: 236-238). Such power, at least in its late $19^{\text {th }}$ and early $20^{\text {th }}$ century formulations, was conceived as instrumental in application and impersonal in character. It flowed from the top-down and was asymmetrically structured; when needed it could deploy coercion and violence to command obedience (Weber 1978:53-54, Sykes 1958, Jacobs 1977, Dilulio 1990). Though the reality and efficacy of this zero-sum understanding of power has been empirically (Sykes 1958, Colvin 1982, Simon 2000) and theoretically (Foucault 1977, Allen 2003, Lukes 2004) much critiqued, it retains a degree of permanence evident, for example, in the direction of official bureaucratization, the self-understanding of prison staff, or the character of institutional prerogatives.

Understood in this more limited way instrumental modes of structuring power use movement as a resource. A capability that facilitates prison order, shores up internal security (through segregation or dispersal) and structures the daily hum of inmate life in time and space (Sparks, Bottoms and Hay, 1996: 273, Kantrowitz 1996: xv, Philo 2001:476). Circular Instruction $10 / 1974$, an administrative control measure that was prominent in the UK until the early 1990s, provides a good example of instrumental modes of deploying movement and their desubjectifying effects. The "ghost-train" or "magic roundabout" (as Cl 10/1974 was known among prisoners) accounted for as many as 100,000 transfers per year and it allowed the governor of one high-security institution to move recalcitrant or dangerous prisoners to special 
segregation cells in local prisons for a 'cooling off period' (Cavadino and Dignan 2007:225). ${ }^{3}$

Though formally justified as necessary to secure 'Good Order and Discipline,' in practice it became an expedient way to circumvent institutional restrictions on the permanent transfer of troublesome prisoners, as well as a powerful tool of coercion and deprivation in its own right; transferred prisoners might move to a new prison every few months, sometimes without ever emerging from punitive detention (Sparks, Bottoms and Hay, 1996: 268-271).

For single institutions control and safety issues remain important drivers of instrumental transfers yet for the broader prison network, questions of security must be weighed alongside the management of population pressures and overcrowding. At the latter level, movement is centrally deployed and works to maintain crowding within the estate's prisons under safe and legally proscribed parameters by redistributing groups of prisoners in line with available places (wherever and whenever those might appear). This shift in scale (from single institutions to networks of prisons) also implies a shift in optics. Prisoners become mere extracts from the actuarial and statistical record, gaining relevance as bundles of favorable characteristics and cross-sections of risk scores (i.e., short sentences close to completion, low flight risk, etc.) that make them suitable for transfer. In UK prisons, this particular mode of managing the problem of fixed spatial resources is known as the 'overcrowding draft' and, as we will see, has become a

\footnotetext{
${ }^{3}$ The relevant section of $\mathrm{Cl} 10 / 1974$ stated: " The purpose of this facility offered to dispersal governors is to provide a brief 'cooling off' period for a troublemaker who needs to be removed from normal location because of an imminently explosive situation caused by either his actual or impending disruptive behaviour, and for whom placement in the segregation unit is inappropriate or impracticable, either because the prisoner would still be able to exercise a disruptive influence from the segregation unit (because of inadequate insulation between the segregation unit and the main prison), or because the extent to which the prisoner provides a focal point for prisoner unrest would mean that the mere act of placement in the segregation unit could have a provocative and explosive effect on the rest of the establishment." $R$. $v$. Deputy Governor Parkhurst Prison, ex parte Hague and Weldon [1992], p.71.
} 
mainstay of prison management under penal populism (Bottoms 1995, Pratt 2007). Finally I should note that despite its centrality, the overcrowding draft remains decidedly low-tech and hence somewhat removed from the sort of algorithmic technologies (Amoore 2008; Amoore and Hall 2009) described by some authors in the context of securitization and border control.

On the other hand much of the contemporary literature on prisons and the 'carceral' or transcarceral (Allspach 2010) forms of power that are connected with and go beyond it, has stressed the point that power within the penal context increasingly takes an embodied and selfdirected form (Vaz and Bruno 2003, Haney 2005; van Hoven and Sibley 2008). Power is said to be decentralized, networked, functioning-at-a distance and nested within systems of surveillance, knowledge and expertise (Foucault 1978; Rose 1989, Miller and Rose 1990, Garland 1997, Dirsuweit 1999, Philo 2001, Simon 2005). Disciplinary techniques increasingly involve strategies of responsibilization and entrepreneurship whereby prisoners are prompted to become agents oriented towards their personal and psychological self-development (Garland 1997:191-192, Liebling 2004, Rose 2000, Allspach 2010). In the UK, official expectations have now moved beyond outward alignment with institutional rules and procedures: prisoners must demonstrate their compliance through psychological assessments and group work, completions of vocational, cognitive behavioral and educational coursework as well as maintaining a clean disciplinary record (Crewe 2009: 115-137).

Disciplinary applications of power produce 'embodied' forms of movement; a point well illustrated by the ideal-typical progression model for IPP (an indeterminate sentence handed out by UK courts between 2005-2012) and other life sentence prisoners (all life sentences in the 
UK are indeterminate). ${ }^{4}$ After sentencing, prisoners are transferred to a local prison (the gateway to the penal estate) where over the course of a few months their life sentence plans are prepared. The plan is a written blueprint of how the inmate's time will be spent detailing: risk evaluations, offending behavior to address and arrangements for doing so, as well as a schedule of reviews and progress reports. Shortly thereafter, they are moved to a first stage prison where more assessments are carried out, plans are finalized and intervention targets set. The self-improvement work begins when the lifer is transferred to a second stage prison though at this point it is unlikely that all the risk reduction targets can be met in the same institution (each prison offers a very limited suite of modules and interventions) so it is common that a prisoner might be subsequently transferred multiple times to access the required resources. Finally, with a release date approaching, the offender would be moved again, this time to prepare for release into the community at a third stage prison (PSO 4700; Pyszora 2010: 198). Within the above context, movement and mobility become embedded components of the custodial sentence binding time, space and movement into a progressive sequence. In the

\footnotetext{
"Though formally called a "life" sentence, all life sentenced prisoners will eventually be eligible for parole upon completion of their minimum term (if the parole board agrees). There are three types of life sentence in the UK: mandatory, discretionary and automatic. Mandatory sentences are the only sanction available for murder, discretionary sentences involve life as the maximum penalty for a serious offense other than murder (e.g., manslaughter, armed robbery, rape etc.) and automatic sentences follow from a second conviction for a serious violent or sexual offense (HMIP and PRT 2001). Indeterminate Sentences for Public Protection (repealed in December 2012) effectively functioned as discretionary life sentences (one received a minimum sentence to serve and could only be released when deemed no longer a threat by the parole board) with three important qualifications: 1) minimum terms were generally shorter than life sentence minimums because the offenses were considered 'less serious' (before the 2008 amendments ca. $1 / 3$ of IPPs had a minimum of 2 years or less); 2 ) they were imposed for crimes that did not carry life as a maximum sentence; and 3) IPPs could apply to have their 'life license' (i.e., lifelong parole supervision) terminated after 10 years (PSO 4700 Lifer Manual 2006:2, Jacobson and Hough 2010:9).
} 
ideal, a prisoner is concurrently moving between different phases of his sentence, different security categories and different kinds of institutions in a staggered trajectory oriented towards release. Though the progressive model is ideal-typical, and most onerous for those prisoners on indeterminate sentences that must rely on it to secure release, it generally describes the sentence trajectory of most determinate medium to long-term prisoners as well. In contrast with instrumental movement, progressive movement is locally arranged and matches institutions with relevant coursework with prisoners in scope to receive them. Thus progressive movement can be identified as one operationalization of the sort of penal leveling described above: prisoners become the carriers of the system's disciplinary grid and link the different institutional spaces they traverse into a recognizable network or system of power. Mobility thus becomes an integral component of the self-governance strategies that have relocated the harness of institutional control within the inmate 'soul' (Foucault 1975) and transformed it into a 'vehicle of power' (Crewe 2011: 524).

Let me be clear. The instrumental and embodied applications of prisoner movement sketched above are not mutually exclusive, nor are they historically determined in the sense that we can chart a movement where one ceases to be applicable and the other becomes dominant. On the contrary they illustrate the dual, often contradictory and enduring premises upon which late-modern penal power rests. A scalar, instrumental model of domination set over and against discrete chains and series of decentralized, individual plans of selfimprovement. Together they generate and sustain divergent Regimes of Circulation. That is, parallel applications of the penal system's apparatus of control where movement becomes an integral component in the maintenance and operation of the power to punish itself. 
In the next section I focus on how ongoing problems of fixed spatial resources, in light of increasing population pressures and estate-wide overcrowding, collided with offender management and sentencing changes introduced by the Criminal Justice Act of 2003. I argue that these changes, which bound the risk-based structuring of custodial sentences to a prisoner's progression through different institutions and temporal benchmarks, helped generate sustained disruptions and fissures in the estate system's circuits of mobility.

\section{Problems of Population}

The British Penal Estate is made up of 133 prisons located in England and Wales. Between 1993 and 2013 the incarcerated population doubled and is currently fluctuating around 85,000 prisoners. This figure represents an approximate overcrowding rate of $10-11 \%$ or 10,000 prisoners over the system's design specifications (i.e. Certified Normal Accommodation) (Ministry of Justice 2013, Scott and Flynn 2014: 136-137). Though this number is not as large as in some other countries (for example the incarcerated population of the state of California in the US more than doubled the system's capacity in the mid-2000s) it also masks some important considerations. Firstly the Certified Normal Accommodation (CNA) figure underestimates overcrowding because a 'normal' degree of overcrowding is already included in it and secondly (as Table 1 illustrates) there is significant variation between institutions in terms of their degree of overcrowding. Thus for example, by the end of June 2013, 56 percent of prisons (69) were overcrowded and nine of these had a population 150 percent of the CNA (Berman and Dar 2013:12). 


\section{[TABLE 1 HERE]}

The above suggest that the prison network routinely operates with little or no capacity to accommodate excess prisoners. Yet administrators, despite having no control over the number of admissions, must find places within their institutions for incoming numbers. In this sense, the penal estate might be likened to a 'push system', to adopt a term more popular in operations and management research. Push systems refer to a manufacturing process where work output moves from one station to the next when it is completed without knowing whether the next station is ready for the increased work (Benton 2010). Because of this push systems can generate costly inventories if the flow of work between stations is not well coordinated ahead of time.

Though prisons are not factories and prisoners are not products, push rationales drive the transportation infrastructure in most prison systems. ${ }^{5}$ As Peck and Theodore (2008) have noted with respect to the correctional system in Illinois, flows in and out of prisons are continuous, large in scale and reflect a rough equilibrium between admissions and releases. In contrast, the UK Penal estate discharges approximately 85,000 individuals per year (a little more than its total population) but receives approximately 120,000 new receptions a year (ca.

\footnotetext{
${ }^{5}$ Though prison management guidelines do not explicitly reference organizational and management texts in the development of policy, it is worth noting that the practices described in this article emerged in connection with a managerial reorganization of the prison and probation service known as the New Managerialism or New Public Management (Hood 1991). This administrative transformation involved the introduction of private sector practices like audits, corporate reports, performance targets, incentive-based performance measures and weighted scorecards (which rank individual prisons quarterly in league tables) amidst stockphrases like 'value for money', 'evidence-based policy', 'quality of service', and 'strategic planning' (Cavadino and Digan, 2007; Loader and Sparks, 2002; Cheliotis 2006; Brownlee 1998: 324-325).
} 
140 per cent of its total population) generating significant flows in and out of prison, as well as between prisons and other criminal justice agencies (approximately 25 percent of new receptions are prisoners on remand) (Table 2). In the context of the limited cell space noted above, this steady overflow of incoming prisoners places continual pressure on administrators to keep individual institutions within acceptable margins through the use of overcrowding drafts and other instrumental forms of movement.

\section{[TABLE 2 HERE]}

A second source of pressure on the estate's transportation system involves the growth in indeterminate sentences, which sit at the far end of the progressive movement continuum. There were 5,147 prisoners serving indeterminate sentences in 2002 and, as illustrated in Table 2 , this number rose to 7,275 in 2006 and then increased to double that by 2012 . Though accounting for only 19 percent of the prison population the bulk of these prisoners were serving new Indeterminate sentences for public protection (IPP) introduced in 2003. Because they involved individuals deemed dangerous to the public, IPP sentences were linked to a series of intervention "packages" (e.g., Cognitive Behavioral Therapy courses) and risk assessment protocols.

One important effect of the introduction of IPPs was the stretching of disciplinary layers and the multiplication of evaluation hurdles not only for these prisoners but also for medium and long-term prisoners more generally. This shift impacted the penal system's mobility patterns dramatically; it introduced new levels of indeterminacy as immobility expanded and average time-served for some categories of prisoners dilated. Because behavioral modules tend to have prerequisites, large waiting lists and yearly enrollment cycles, prisoners under the new 
sentences spent significant time in long queues, waiting for places on specialized courses at different institutions (mandatory if they hoped to be considered for parole) (Strickland and Grimwood 2013). For example, Acklington prison, one of four institutions that ran the Healthy Relationships Programme in 2009, had 16 places per year and a two-year waiting list (HMIP 2009a: 97-98). Similarly, HMP Long Lartin one of five institutions that offered the Cognitive Self-Change Programme in 2011 had 6 places per year and a 3-year waiting list (HMIP 2011c: 76). While some queued for courses, others waited idly for sentencing plan reviews and risk assessments to be undertaken or completed.

In the context of the wider push network described above, progressive movement increasingly took the form of a mini 'pull' system. Pull systems refer to manufacturing processes (e.g., Just-in-Time or Lean Production) where work moves from one station to the next only when the next station demands it. The emphasis is on communication and scheduling because pull systems function with little or no inventories and thus impose very high transaction costs whenever the temporal sequencing of events is disrupted (Castells 1996:157; Harvey 1989: 175178; Sadler 1994: 42-43). In the penal estate, prisoners sit on waiting lists for places at institutions with interventions. When both cell space and an intervention slot become available the prisoner gets 'pulled' from their current locale into the new position (presumably leaving open cell space for the next person in line).

Push and pull imperatives produce divergent trajectories of movement and pose systemic challenges when implemented concurrently. As more prisoners move through the network and overcrowding levels remain high, transfers between institutions for progressive reasons become more difficult because they are in competition with prisoner movements 
designed to generate cell-space and relieve crowded conditions (IMB 2009d: 27; 2010: 30; IMB 2012b: 28). Indeed, the situation for IPP prisoners pre and post 2008 is a good illustration of how push and pull mechanisms work against one another to generate 'interruptions' in the estate system's circuitry of power.

Risk assessments and sentence plans are dependent on the availability of specialist staff and their workloads, as well as the input of multiple actors in different locales (IMB 2010a: 2021; IMB Garth 2010b: 54). By 2008, assessment wait times for IPP prisoners had become so acute that the progressive sequence was amended to allow them to skip first-stage lifer prisons and progress directly from local prisons to second-stage training prisons (Jacobson and Hough, 2010: 69). This alleviated the strain on the gateway institutions (local prisons) where assessments are performed but pushed this disruption further down the institutional chain and deep into the penal estate. Those prisons providing specialized courses open not only to IPP prisoners but other lifers and medium term prisoners, now faced pressure to move their current populations onto open prisons (where offenders prepare for release into the community) to make way for the new incoming cohorts.

Thus what came to characterize progressive movement under these conditions was hardly the sort of linear, continuous and embodied fusion of space-time trajectories envisaged by administrators and officials. Instead, fissure zones appeared in the prison's temporal order as pockets of acceleration, deceleration and inertia proliferated and expanded across the penal estate. In the next section, I examine these disruptions and contradictions up close by mapping the broad institutional trajectories of penal flows. 


\section{Scaling Penal Flows}

Virtually all prisoner escorts in the British penal estate and the wider criminal justice system are provided by Prisoner Escort and Custody Service (PECS) or Secure Escort Services for Children and Young People (SESCYP); the PECS contract is shared among the private security firms GEOAmey and Serco (Wincanton, a supply chain solution provider is a joint-partner), the SESCYP contract is handled exclusively by Serco (HMIP 2014:5). Table 3 summarizes selected prisoner transportation data for the criminal justice system over 3 months in 2013-2014. The scale of this movement is substantial $(189,069$ escorts), as is its annual cost of $£ 137.3$ Million (HMIP 2014:5). As the data illustrates, the greater volume of traffic (46\%) is located at the front-end of the penal estate in 'local' prisons, the initial receiving points for transfers from police stations or the courts and the gateway into the penal estate. Local prisons (much like American "jails" in the prison systems of individual states) process prisoners with divergent temporal and mobility horizons: a) they serve the courts in their area (i.e., they house remanded and unsentenced prisoners); b) accommodate sentenced prisoners awaiting transfer to other institutions and; c) are where most short-term sentences (under 12 months but more often under 6 months) will be served.

\section{[TABLE 3 HERE]}

Given the numbers involved looping, steering, and queuing the movement of these different populations remains a considerable challenge. For example, HMP Highdown processes 430 new receptions and 600 movements between it and the courts per month (HMIP 2009h, 18). Yet significantly smaller institutions like HMP Bedford (CNA of 506) also feel the strain of 
the push system balancing 7,670 receptions against 8,270 exits per year (IMB 2012: 14). And even these numbers represent just a small proportion of the 80,000 prisoners that shuffle between the courts and local prisons estate-wide per month (HMIP 2011a: 25). Local prisons are central nodes in the system's mobility network: they sift, sort and link individual trajectories of spatio-temporal movement with the dominant regimes of prisoner circulation in the estate. Because of their high turnovers and the transient nature of their prisoners, the bulk of their role is primarily one of facilitating movement between prisons, between prisons and other justice institutions and between the prison system and the outside. Even for short-term prisoners serving sentences there, imprisonment is closer in character to temporary detention (i.e., few programmed activities, interventions and self-improvement opportunities) than it is to the rest of the penal estate.

As I argued in the previous section, the introduction of new indeterminate sentences in the Criminal Justice Act of 2003 (as well as the changes in offender management they embodied) effectively multiplied and lengthened the disciplinary segments that make up the progressive chain. In terms of the broader estate mobility system, the full impact of this was felt between 2007 and 2010. Indeed between 2007 and 2009 there were 270,000 transfers across prisons in England and Wales-an average of 2,600 inter-prison transfers per week (Ministry of Justice 2010:7). Throughout this period the contradictory rationales that shaped and drove prisoner movement were brought into sharp relief producing corridors of high traffic, chains of dislocation and islands of 'dead time'.

If one were to map the broad trajectories of inter-prison flows two corridors of traffic stand out: movements from the South West of the country to the South East and movements 
from London and the South West to the Midlands and the North West. One prominent example of this movement and the wider displacement patterns it produced involves local prisons in the London area, HMP Birmingham and HMP Liverpool. Besides serving the courts in its area, Birmingham (a local male prison) would receive sometimes daily overcrowding drafts from London prisons and would displace an equal number of its local prisoners further North to Liverpool or to HMP Forest Bank (HMIP 2007a: 61; HMIP 2009j:10; 2012 and HMIP 2007b: 19; 2009c:22,45, 89; 2011b:21; HMIP 2010b:90). Not surprisingly this created a domino effect in that HMP Liverpool (also a local prison) had to displace its own prisoners to other institutions to free up cell space for Birmingham inmates. Traffic also flowed from other directions: HMP Durham (another local prison in the Northeast) would generate fortnightly drafts to and from Edinburgh as well as 50 weekly transfers to prisons in the Northwest (HMIP 2009d: 91).

Displacement and dislocation clearly disrupted ongoing processes of assessment and intervention delivery but they also introduced significant discontinuity at multiple levels of institutional life. Prisoners were transferred before risk assessments were completed or coursework was finished (HMIP 2011d: 55), they missed healthcare visits or appointments. It was not uncommon for prisoners to be informed on the morning or night before the move that they had been "drafted" and so relatives arrived for visit days to find their loved ones already moved; links with legal advisors, property and entitlements were routinely interrupted (HMIP 2009j: 45-46). At its most extreme displacement could mean that prisoners on their way to court would take property and cash with them because they could not be certain that they would return to the same prison in the evening (HMIP 2007b:21). Or, that unconvicted prisoners still due to be sentenced in court would be transferred to a facility 100 miles away 
(HMIP 2009k: 60). The ideal typical prisoner for an overcrowding draft is a low security risk and serving a short-term sentence with less than six months left (NAO 2005: 26; HMIP 2009e: 80). Short-term prisoners also have the highest reoffending rates in the correctional population and are released into the community without any further supervision. Moving prisoners so close to release impacts what prison administrators have identified as key pathways to reducing reoffending such as the organization of housing, employment and the maintenance of community and family ties.

The instrumental and de-subjectifying effect of overcrowding transfers is evident from the next example. Over the course of four months in 2009, HMP Hewell (a "training" prison in the Midlands) received 237 prisoners from London and 59 from the South West on overcrowding drafts (HMIP 2009g: 18-19). Many of these prisoners were within five weeks of release and would require transportation South again soon, but instead they were transferred North to HMP Altcourse to free up space at Hewell (HMIP 2010a:17). In contrast, Hollesly Bay, an open prison that prepares prisoners for re-entry into the community struggled to provide services and interventions for an increasingly transient population: 1 in 4 prisoners released from there had been at the institution less than one week (HMIP 2009i: 53). Thus for prisoners subject to overcrowding drafts transfers can occur with astounding rapidity and strain the capacity of local prisons to bureaucratically manage this throughput efficiently. At the same time, because "training" prisons place caps on the number of prisoners in certain security and sentence categories they are willing to accept, local prisons often become "holding" sites for prisoners awaiting progressive moves. For example, at the time of its inspection, HMP Belmarsh (a local prison in London) had 99 life-sentenced prisoners awaiting progressive 
transfer. Over half of this population spent most of their day locked in their cells; most were unable to achieve any sentence objectives at Belmarsh or to transfer out to more suitable institutions because of overcrowding (HMIP 2009b: 5, 14).

Although the Legal Aid, Sentencing and Punishment of Offenders Act of 2012 abolished Indeterminate Sentences for Public Protection, there were 5,335 IPPs in the penal estate as of December $31^{\text {st }} 2013$. Sixty-seven per cent of these were well beyond their minimum term (approximately half have been in prison since before 2008) and only 60 percent had completed at least one offending behavior program (Hansard's Lords Debate, 5.6.2014, C399W). As one MP recently noted, "at the current rate of release...it could take nine years to clear the backlog" (Hansard's Lords Debate 3.27.2014, C685). The scarcity of intervention programs continues to be problematic, as does overcrowding throughout the penal system, in part because (as we will see in a moment) the government's focus has shifted from managing progressive circulation in the penal estate to extending these circulation structures into the community.

\section{Extending the Carceral Chain}

Prison systems form part of larger carceral assemblages or networks: island-chains of steering institutions, social control mechanisms and surveillance regimes that work to regulate, reify and redraw the boundaries of conduct, belonging and eligibility (Peck 2003; Peck and Theodore 2008; Beckett and Herbert 2009). Though incarceration may very well have a spatiotemporal terminus, release from custody is by no means the end of the story. To cite just 2 examples: both California and Illinois have averaged at least one new prison per year between 
the mid-1980s and mid-2000s (Peck and Theodore 2008:252-253; Gilmore 2007:7). Demand continues to rapidly outpace supply. In Britain, the government built 9 new prisons between 1995 and 2007 and spent significant resources expanding capacity on existing sites. As of November 2014, it has approved a new 'titan' prison in North East Wales. Wrexham prison will be massive by UK standards, housing more than 2,000 prisoners and strategically located in a region of high circulation: it will serve North Wales, the Midlands and the North West of England. Echoing what Gilmore (2007) and others (Che 2005, Bonds 2013) have noted in the US context, the promotional material for the new institution located on the site of a former Firestone rubber factory, highlights the 1,000 new jobs that will be created and the $f 23$ million of additional revenue it will bring to the region (Ministry of Justice 2013).

Clearly the prison has become an increasingly prominent political economic catchall not just for intractable problems of social control but also labor market regulation (Wacquant 2010; Peck and Theodore 2008) and regional restructuring (Bonds 2009; Gilmore 2007). Scholars have highlighted the entanglements and intimate relationships that have developed between hyper-incarceration, rural settings and urban neighborhoods where whole districts have become anchor points for the relentless churn of movements in and out of prison (Wacquant 2001, 2009, Mitchelson 2012). This paper has sought to supplement these analyses by treating the penal side of the carceral chain. I have noted that contemporary imprisonment involves a spatio-temporal process characterized by the tension and oscillation between periods of sustained idleness and enforced mobility (Martin and Mitchelson 2009:463; Moran 2013). I have linked this dialectic to countervailing modes of operationalizing "power in motion" arguing that instrumental and embodied forms of movement have become important components in 
the maintenance and operation of penal power. I have examined the patterns of mobility, corridors of traffic and trajectories of displacement that these regimes of circulation produced in the British Penal Estate's recent history and discussed them in the context of estate-wide overcrowding and the restructuring of indeterminacy frameworks.

In conclusion I would like to briefly note some of the carceral rearrangements that are currently bridging and interfacing the transportation frameworks inside with the 'circuitry of security' (Rose 2000) outside. Recent sentencing changes appear to extend the reach of the prison into the community and to externalize some of the mobility problems (and control structures) identified in this paper. For example, the new Extended Determinate Sentences that have replaced IPPs since 2012 will lengthen the average custodial term and involve 'extended', more intensive periods of supervision in the community (up to 5 years for violent offenses and 8 years for sexual offenses). Similarly, the Offender Rehabilitation Act of 2013 will extend new supervision, surveillance and behavioral intervention requirements to short-term sentences, which up until this point have been released into the community with no supervision or followup whatsoever. Importantly for the two most prevalent short-term sentences (6 months and 10 months) the custodial portion will be half of the sentence (as has always been the case) but now there will be a new license and post-sentence supervision period to be served in community.

The above 'package' will expand the surveillance of short-term prisoners released from custody to a total of 12 months and represents a dramatic widening, deepening and lengthening of the carceral chain. It is also likely that these new supervision arrangements will echo the pattern scholars have noted in the American context (in terms of coercive mobility 
and labor market regulations) since the requirements come bundled with a suite of regulatory restrictions that impact relocation, employment and travel considerations. Finally it should be noted that the very structures of supervision, surveillance, and intervention meant to target short-term offenders (which account for some $65 \%$ of all sentenced admissions and releases [NAO 2010: 4]) are themselves being restructured. The 35 Probation Trusts that previously managed offenders in the community have now been replaced by a single National Probation service (for high-risk offenders) and 21 Community Rehabilitation Companies (for low and medium risk offenders). This new division of labor shifts the bulk of probationer and parolee management to the private sector and likely will accelerate the dominance of economic rationales and market imperatives in the delivery of social and crime control. 
Table 1

Overcrowded prisons in UK Penal Estate, June 2013

Capacity (CNA) Population Percentage

Overcrowded

\begin{tabular}{l|l|l|l} 
Wandsworth & 709 & 1,243 & $175 \%$ \\
\hline Swansea & 240 & 402 & $168 \%$ \\
\hline Exeter & 317 & 518 & $163 \%$ \\
\hline Leicester & 210 & 323 & $154 \%$ \\
\hline Cardiff & 539 & 782 & $145 \%$ \\
\hline Bristol & 427 & 608 & $142 \%$ \\
\hline Thameside & 600 & 836 & $139 \%$
\end{tabular}

Source: Ministry of Justice (2013)

Table 2

Flows through UK Penal

Estate, 2006-2012

\begin{tabular}{|c|c|c|c|c|c|c|c|}
\hline & 2006 & 2007 & 2008 & 2009 & 2010 & 2011 & 2012 \\
\hline $\begin{array}{l}\text { Prison } \\
\text { Population }\end{array}$ & 77,982 & 79,734 & 83,194 & 83,454 & 85,002 & 85,374 & 86,048 \\
\hline $\begin{array}{l}\text { Serving } \\
\text { Determinate } \\
\text { Sentences }\end{array}$ & 70,707 & 70,253 & 71,812 & 70,933 & 71,868 & 71,730 & 72,294 \\
\hline $\begin{array}{l}\text { Serving } \\
\text { Indeterminate } \\
\text { Sentences }\end{array}$ & 7,275 & 9,481 & 11,382 & 12,521 & 13,134 & 13,644 & 13,754 \\
\hline $\begin{array}{l}\text { New } \\
\text { Receptions } \\
\text { (includes } \\
\text { prisoners on } \\
\text { remand) }\end{array}$ & 128,986 & 125,881 & 134,148 & 125,877 & $\begin{array}{l}\text { Not } \\
\text { available }\end{array}$ & 120,760 & 112,772 \\
\hline $\begin{array}{l}\text { New } \\
\text { sentenced } \\
\text { prisoners }\end{array}$ & 90,038 & 91,736 & 100,348 & 94,964 & $\begin{array}{l}\text { Not } \\
\text { available }\end{array}$ & 90,955 & 86,479 \\
\hline Discharges & 82,400 & 85,500 & 94,900 & 91,200 & 89,666 & 85,540 & 85,525 \\
\hline
\end{tabular}

Source: Ministry of Justice

(2012) 


\section{Table 3}

Number of Adult Escorts in the UK Criminal Justice System by Selected Type,

Nov. 2013-Jan.31 2014

\begin{tabular}{l|l|l|l|l|l} 
Type of Escort & $\begin{array}{l}\text { Adult } \\
\text { Men }\end{array}$ & $\begin{array}{l}\text { Young } \\
\text { Adult } \\
\text { Men } \\
\mathbf{( 1 8 - 2 1 )}\end{array}$ & $\begin{array}{l}\text { Adult } \\
\text { Women }\end{array}$ & $\begin{array}{l}\text { Young } \\
\text { Adult } \\
\text { Women } \\
\mathbf{( 1 8 - 2 1 )}\end{array}$ & Totals (\%) \\
\hline $\begin{array}{l}\text { Total Transfers } \\
\text { to Police } \\
\text { Stations }\end{array}$ & 832 & 74 & 61 & 9 & $\begin{array}{l}976 \\
(1 \%)\end{array}$ \\
\hline $\begin{array}{l}\text { Total Transfers } \\
\text { to Courts }\end{array}$ & 81,313 & 10,203 & 8,449 & 686 & $\begin{array}{l}100,651 \\
(53 \%)\end{array}$ \\
\hline $\begin{array}{l}\text { Prisons/YOI to } \\
\text { Courts }\end{array}$ & 37,134 & 4,904 & 2,839 & 199 & $\begin{array}{l}45,076 \\
(24 \%)\end{array}$ \\
\hline $\begin{array}{l}\text { Total Transfers } \\
\text { to Prisons/YOIs }\end{array}$ & 72,660 & 9,153 & 5,266 & 343 & $\begin{array}{l}87,422 \\
(46 \%)\end{array}$ \\
\hline $\begin{array}{l}\text { Inter- } \\
\text { prison/YOI } \\
\text { Transfers }\end{array}$ & 14,474 & 1,922 & 485 & 24 & $\begin{array}{l}16,905 \\
(9 \%)\end{array}$ \\
\hline Totals & 154,822 & 19,431 & 13,777 & 1,039 & 189,069
\end{tabular}

Source: HM Inspectorate of Prisons (2014) 
References:

Adey P, 2004, "Secured and Sorted Mobilities: Examples from the Airport" Surveillance and Society 1(4) 500-519.

Adey P, Bevan P, 2006, "Between the Physical and the Virtual: Connected Mobilities," in Mobile Technologies of the City Eds M Sheller, J Urry (London, Routledge) pp. 44-60.

Allen J, 2003, Lost Geographies of Power (Oxford, Melbourne, Berlin, Blackwell).

Allspach A, 2010, "Landscapes of (Neo-)liberal Control: the Transcarceral Spaces of Federally Sentenced Women in Canada" Gender, Place and Culture 17(6), 705-723.

Amoore L, Hall A, 2009, "Taking People Apart:Digitised Dissection and the Body at the Border" Environment and Planning D: Society and Space 27(3), 444-464.

Amoore L, 2009, "Everyday Geographies of the War on Terror" Antipode 41(1), 49-69.

Amoore L, 2009, "Lines of Sight: On the Visualization of Unknown Futures" Citizenship Studies 13(1), 1730.

Beckett K, Herbert S, 2009, Banished: The New Social Control in Urban America (Oxford and New York, Oxford University Press)

Benton WC, 2010 "Push and Pull Production Systems," in Wiley Encyclopedia of Operations Research and Management Science Ed J Cochran (London, Wiley).

Berman G, Dar A, 2013 “Prison Population Statistics," Commons Library Standard Note (SN04334) (London, House of Commons).

Bonds A, 2009, "Discipline and Devolution: Constructions of Poverty, Race, and Criminality in the Politics of Rural Prison Development 41(3), 416-438.

Bonds A, 2013, "Economic Development, Racialization, and Privilege" 'Yes in My Backyard' Prison Politics and the Reinvention of Madras, Oregon" Annals of the Association of American Geographers 103(6), 1389-1405.

Bottoms A, 1995, "The Philosophy and Politics of Punishment and Sentencing," in The Politics of Sentencing Reform Eds Clarkson C, R Morgan (Oxford: Clarendon)

Brownlee I, 1998, "New Labour-New Penology? Punitive Rhetoric and the Limits of Managerialism in Criminal Justice Policy", Journal of Law and Society 25(3): 313-335.

Castells M, 1997, The Power of Identity, The Information Age: Economy, Society and Culture Vol. II (Cambridge, MA and Oxford, UK, Blackwell). 
1996, The Rise of the Network Society, The Information Age: Economy, Society and Culture Vol. (Cambridge, MA and Oxford, UK, Blackwell).

Cavadino M, Dignan J, 2007, The Penal System: An Introduction (London, Sage).

Che D, 2005, "Constructing a Prison in the Forest: Conflicts Over Nature, Paradise, and Identity" Annals of the Association of American Geographers 95(4), 808-831.

Cheliotis LK, 2006, "Penal Managerialism From Within: Implications for Theory and Research," International Journal of Law and Psychiatry 29: 397-404.

Clear T, Rose D, Waring E, Scully K, 2003, “Coercive Mobility and Crime: A Preliminary Examination of Concentrated Incarceration and Social Disorganization" Justice Quarterly 20(1), 33-63.

Clear T, Imprisoning Communities: How Mass Incarceration Makes Disadvantaged Neighborhoods Worse (New York, Oxford University Press).

Clemmer D, 1958, The Prison Community, (New York, Holt, Rinehart and Winston).

Cohen S, Taylor L, 1972, Psychological Survival (New York, Vintage Books).

Cohen S, 1985, Visions of Social Control (Malden, MA, Polity Press).

Colvin M, 1982 “The New Mexico Prison Riot” Social Problems 29(5) 449-463.

Cresswell T 2006, "The Right to Mobility: The Production of Mobility in the Courtroom," Antipode, 38 (4) 735-754.

Cresswell T 2001 The Tramp in America (London, Reaktion Books).

Cresswell T 1999, "Embodiment, Power and the Politics of Mobility: the Case of Female Tramps and Hobos," Transactions of the Institute of British Geographers, 24 (2) 175-192.

Cresswell T 1997, "Imagining the Nomad: Mobility and the Postmodern Primitive," Space and Social Theory: Interpreting Modernity and Postmodernity, Eds. G. Benki, U. Stohmayer (Eds.), (Blackwell, Oxford), pp. 360-382

Crewe B, 2011a, "Depth, Weight, Tightness: Revisiting the Pains of Imprisonment," Punishment and Society 13 (5) 509-529.

Crewe B 2011b, "Soft Power in Prison: Implications for Staff-Prisoner Relationships, Liberty and Legitimacy," European Journal of Criminology 8 (6) 455-468.

Crewe B 2009, The Prisoner Society: Power, Adaptation and Social Life in an English Prison (Oxford, Oxford University Press).

Davis A, 2003, Are Prisons Obsolete? (New York, Seven Stories Press) 
De Giorgi A, 2006, Re-Thinking the Political Economy of Punishment (Hampshire, UK and Burlington, VT, Ashgate).

Desmond M, Valdez N, 2013, "Unpolicing the Urban Poor: Consequences of Third-Party Policing for Inner-City Women" American Sociological Review 78(1)117-141.

Dilulio J, 1987, Governing Prisons: A Comparative Study of Correctional Management (New York, The Free Press).

Diken B, Albertsen N, 2001, "Mobility, Justification and the City," Nordic Journal of Architectural Research 14 (1): 13-24.

Dirsuweit T, 1999, "Carceral Spaxes in South Africa: A Case study of Institutional Power, sexuality and Transgression in a Women's Prison" Geoforum 30(1), 71-83.

Elias N, 1985, The Civilizing Process (Oxford, Blackwell).

Feeley M M, Simon J, 1992, "The New Penology: Notes on the Emerging Strategy of Corrections and its Implication," Criminology 30 (4) 449-474.

Foucault M, 1975, Discipline and Punish: The Birth of the Prison (New York, Random House)

Franquesa J, 2011, “'We've Lost Our Bearings': Place, Tourism, and the Limits of the 'Mobility Turn'” Antipode 43 (4) 1012-1033.

Garland D, 2001, The Culture of Control (Chicago, University of Chicago Press).

Garland D, "Governmentality" and the Problem of Crime: Foucault, Criminology, Sociology," Theoretical Criminology 1 (2) 173-214.

Germann Molz J, 2006, “'Watch us Wander': Mobile Surveillance and the Surveillance of Mobility" Environment and Planning A 38 (2) 377-393.

Gill N, 2009a, "Longing for Stillness: The Forced Movement of Asylum Seekers" M/C Journal 12(1). Available at: http://journal.media-culture.org.au/index.php/mcjournal/article/viewArticle/123.

Gill N, 2009b, "Governmental Mobility: The Power Effects of the Movement of Detained Asylum Seekers around Britain's Detention Estate," Political Geography 28 (3) 186-196.

Glimore RW, 2007, Golden Gulag: Prisons, Surplus, Crisis and Opposition in Globalizing California (Berkley, University of California Press).

Gogia N, 2006, "Unpacking Corporeal Mobilities: the Global Voyages of Labour and Leisure," Environment and Planning A 38(2) 359-375.

Gros JM, McInnis KR, 2003, Kanban Made Simple: Demystifying and Applying Toyota's Legendary Manufacturing Process (New York, American Management Association). 
Hannan K, Sheller M, Urry J, 2006,Editorial, "Mobilities, Immobilities and Moorings," Mobilities 1(1) 122.

Harvey D, 1989, The Condition of Post-Modernity (Cambridge, Mass., Blackwell).

Haney C, 2005 "The Contextual Revolution in Psychology and the Question of Prison Effects" The Effects of Imprisonment, Eds A Liebling, S Maruna (London and New York, Routledge),66-93.

Haney C, 2003, "Mental Health Issues in Long-Term Solitary and Supermax Confinement," Crime \& Delinquency, 49 (1) 124-156.

Hetherington K, 2000, New Age Travellers: Vanloads of Uproarious Humanity (London, Cassell).

HM Chief Inspector of Prisons, 2012, Report on an unannounced inspection of HMP Birmingham (London, Her Majesty's Inspectorate of Prisons).

HM Chief Inspector of Prisons, 2011a, Annual Report 2011-2012 (London, Her Majesty's Inspectorate of Prisons).

HM Chief Inspector of Prisons, 2011b, Report on an unannounced full follow-up inspection of HMP Liverpool (London, Her Majesty's Inspectorate of Prisons).

HM Chief Inspector of Prisons, 2011c, Report on a full unannounced inspection of HMP Whitemoor (London, Her Majesty's Inspectorate of Prisons).

HM Chief Inspector of Prisons, 2011d, Report on an unannounced full follow-up inspection of HMP Wormwood Scrubs (London, Her Majesty's Inspectorate of Prisons).

HM Chief Inspector of Prisons, 2010a, Report on an unannounced full inspection of HMP Altcourse (London, Her Majesty's Inspectorate of Prisons).

HM Chief Inspector of Prisons, 2010b, Report on an unannounced full inspection of HMP Forest Bank (London, Her Majesty's Inspectorate of Prisons).

HM Chief Inspector of Prisons, 2009a, Report on an unannounced full follow-up inspection of HMP Acklington (London, Her Majesty's Inspectorate of Prisons).

HM Chief Inspector of Prisons, 2009b, Report on an unannounced full follow-up inspection of HMP Belmarsh (London, Her Majesty's Inspectorate of Prisons).

HM Chief Inspector of Prisons, 2009c, Report on an unannounced full follow-up inspection of HMP Birmingham (London, Her Majesty's Inspectorate of Prisons).

HM Chief Inspector of Prisons, 2009d, Report on an unannounced full inspection of HMP Durham (London, Her Majesty's Inspectorate of Prisons).

HM Chief Inspector of Prisons, 2009e, Report on announced inspection of HMP Exeter (London, Her Majesty's Inspectorate of Prisons). 
HM Chief Inspector of Prisons, 2009f, Report on an unannounced full follow-up inspection of HMP Garth (London, Her Majesty's Inspectorate of Prisons).

HM Chief Inspector of Prisons, 2009g, Report on an announced inspection of HMP Hewell (London, Her Majesty's Inspectorate of Prisons).

HM Chief Inspector of Prisons, 2009h, Report on an unannounced follow-up inspection of HMP \& YOI High Down (London, Her Majesty's Inspectorate of Prisons).

HM Chief Inspector of Prisons, 2009i, Report on an announced inspection of HMP Hollesley Bay (London, Her Majesty's Inspectorate of Prisons).

HM Chief Inspector of Prisons, 2009j, Report on an announced inspection of HMP Liverpool (London, Her Majesty's Inspectorate of Prisons).

HM Chief Inspector of Prisons, 2009k, Report on an announced inspection of HMYOI Reading (London, Her Majesty's Inspectorate of Prisons).

HM Chief Inspector of Prisons, 2007a, Report on an announced inspection of HMP Birmingham (London, Her Majesty's Inspectorate of Prisons).

HM Chief Inspector of Prisons, 2007b, Report on an unannounced full inspection of HMP Liverpool (London, Her Majesty's Inspectorate of Prisons).

HM Inspectorate of Probation and Prisons, 2013, A Joint Inspection of Life Sentence Prisoners (London, Her Majesty's Inspectorate of Probation and Prisons).

HM Inspectorate of Prisons and Probation, 2011, A Joined-up Sentence? Offender Management in Prisons 2009-2010 (London, Her Majesty's Inspectorate of Prisons and Probation).

HM Inspectorate of Prisons, 2014, Transfers and Escorts Within the Criminal Justice System (London, Her Majesty's Inspectorate of Prisons).

Hood C, 1991, “A Public Management for All Seasons?" Public Administration 69(1) 3-19.

van Hoven B, Sibley D, 2008, "'Just Duck': the Role of Vision in the Production of Prison Spaces" Environment and Planning D: Society and Space 26(6) 1001-1017.

Imrie R, 2000, "Disability and Discourses of Mobility and Movement" Environment and Planning A 32(9) 1641-1656.

Independent Monitoring Board, 2012a, HMP Bedford: Annual Report, 2011-2012 (London, IMB).

Independent Monitoring Board, 2012b, HMP Highpoint: Annual Report, 2012 (London, IMB).

Independent Monitoring Board, 2010a, HMP Blundestone: Annual Report, July 2009-June 2010 (London, IMB). 
Independent Monitoring Board, 2010b, HMP Garth: Annual Report, December 2009-November 2010 (London, IMB).

Independent Monitoring Board, 2010c, HMP Leeds: Report 2010 (London, IMB).

Independent Monitoring Board, 2010d, HMP Long Lartin: Annual Report, February 2009- January 2010 (London, IMB).

Irwin J, 2005, The Warehouse Prison: Disposal of the New Dangerous Class (Los Angeles, Roxbury Press).

Irwin J, 1985, The Jail: Managing the Underclass in American Society (Berkley and Los Angeles, University of California Press).

Irwin J, 1980, The Felon (Berkley and Los Angeles, University of California Press).

Jacobs J, 1977, Stateville: The Penitentiary in Mass Society (Chicago, University of Chicago Press).

Jacobson J, Hough M, 2010, Unjust Deserts: Imprisonment for Public Protection (London, Prison Reform Trust).

Johnson R, "Brave New Prisons: the Growing Social Isolation of Modern Penal Institutions" The Effects of Imprisonment, Eds A Liebling, S Maruna (London and New York, Routledge), 255-285.

Kofman E, 2002, "Contemporary European Migrations: Civic Stratification and Citizenship," Political Geography 218 1035-54.

Kurki L, Morris N, 2001, "The Purposes, Practices, and Problems of Supermax Prisons," Crime and Justice 28 385-424.

Law R, 1999, "Beyond 'Women and Transport': Towards New Geographies of Gender and Daily Mobility" Progress in Human Geography 23(4) 567-588.

Liebling A, (assisted by H. Arnold), 2004, Prisons and their Moral Performance: A Study of Values, Quality, and Prison Life (Oxford, Clarendon Press).

Loader I, Sparks R, 2002, "Contemporary Landscapes of Crime, Order and Control: Governance, Risk and Globalization" The Oxford Handbook of Criminology, 3rd Edition Eds. M Maguire, R Morgan and R Reiner (Oxford, Oxford University Press).

Lukes S, 2004, Power: A Radical View (Basingstroke, Palgrave Macmillan).

Martin L, Mitchelson M, 2009, "Geographies of Detention and Imprisonment: Interrogating Spatial Practices of Confinement, Discipline, Law and State Power" Geography Compass 3(1), 459-477.

Mears D, Reisig M, 2006 "The Theory and Practice of Supermax Prisons," Punishment \& Society 8 (1) 3357. 
Mitchell D, "The Annihilation of Space by Law: The Roots and Implications of Anti-Homeless Laws in the United States," Antipode 29 (3) 303-335.

Mitchelson M, 2012, "Research Note- The Urban Geography of Prisons: Mapping the City's "Other" Gated Community" Urban Geography 31(1):147-157.

Ministry of Justice, 2013, Story of the Prison Population: 1993 - 2012 England and Wales (London, Ministry of Justice)

Miller P, Rose N, 1990, “Governing Economic Life” Economy and Society 19(1), 1-31.

Ministry of Justice, 2010, Review of Prison Transfers Prior to HMCIP Inspections (London, Ministry of Justice).

Moran D, 2013, "Between Outside and Inside? Prison Visiting Rooms as Liminal Carceral Spaces" GeoJournal 78 (2) 339-351.

Moran D, 2013, "Carceral Geography and the Spatialities of Prison Visiting: Visitation, Recidivism and Hyperincarceration," Environment and Planning D: Society and Space 31 (1) 174-190.

Moran D, 2012, "Prisoner Reintegration and the Stigma of Prison Time Inscribed on the Body" Punishment \& Society 14 (5) 564-583.

Moran D, 2012," 'Doing Time' in Carceral Space: TimeSpace and Carceral Geography" Geografiska Annaler B 94 (4) 305-316.

Moran D, Piacentini L, Pallot J, 2011, "Disciplined Mobility and Carceral Geography: Prisoner Transport in Russia," Transactions of the Institute of British Geographers 37(3) 446-460.

Mountz A, Coddington K, Catania RT, Loyd J, 2013, "Conceptualizing Detention: Mobility, Containment, Bordering and Exclusion" Progress in Human Geography 37(4), 522-541.

National Audit Office, 2005, National Offender Management Service: Dealing with Increased Numbers in Custody. London: National Audit Office.

National Audit Office, 2010, Managing Offenders on Short Custodial Sentences. London: National Audit Office.

National Offender Management Service, 2013, Prison Population Monthly Bulletin: June 2013 (London, Ministry of Justice).

Neumayer E, 2006, "Unequal Access to Foreign Spaces: How States Use Visa Restrictions to Regulate Mobility in A Globalized World," Transactions of the Institute of British Geographers 31(1) 72-84.

Peck J, 2003,"Geography and Public Policy: Mapping the Penal State" Progress in Human Geography 27(2) 222-232. 
Peck J and Theodore N, 2008, "Carceral Chicago: Making the ex-offender Employability Crisis" International Journal of Urban and Regional Research 32(2), 251-281.

Pratt J, 2007, Penal Populism (Abingdon: Routledge).

Pyszora N, 2010, "The Lifer System in England and Wales" Psychiatry in Prisons: A Comprehensive Handbook, Eds Wilson S, Cumming I (London and Philadelphia, Jessica Kingsley Publishers).

Rhodes L, 2004, Total Confinement: Madness and Reason in the Maximum Security Prison (Berkley and London, University of California Press).

Rosa H, 2013, Social Acceleration: A New Theory of Modernity (New York, Columbia University Press).

Rose N, 1989, Governing the Soul: the Shaping of the Private Self (London and New York, Routledge)

Rose N, 2000, "Government and Control" British Journal of Criminology 40 (2), 321-339.

Sadler D, 1994, "The Geographies of Just-in-Time: Japanese Investment and the Automotive Components Industry in Western Europe" Economic Geography 70(1) 41-59.

Sager T, 2006 "Freedom as Mobility: Implications of the Distinction between Actual and Potential Travelling," Mobilities 1 (3) 465-88.

Scarce R, 2002,"Doing Time as an Act of Survival." Symbolic Interaction 25 (3) 303-321.

Schuster L, 2005, "The Continuing Mobility of Migrants in Italy: Shifting between Places and Statuses," Journal of Ethnic and Migration Studies 31 (4) 757-74

Scott D, Flynn N, 2014, Prisons and Punishment: The Essentials (Los Angeles, London, New Delhi and Singapore, Sage).

Shubin S, 2011, “'Where can a Gypsy Stop?' Rethinking Mobility in Scotland," Antipode 43(2) 494-524.

Sim J, 2009, Punishment and Prisons: Power and the Carceral State (Thousand Oaks Ca., Sage).

Simon B, 2005, "The Return of Panopticism: Supervision, Subjection and the New Surveillance" Surveillance and Society 3(1), 1-20.

Simon J, 2000, "The 'Society of Captives' in the Era of Hyper-Incarceration' Theoretical Criminology 4(3): 285-308.

Sparks R, Hay W, Bottoms A, 1996, Prisons and the Problem of Order (Oxford, Clarendon Press).

Strickland P, Grimwood G, 2013, "The Abolition of Sentences of Imprisonment for Public Protection" (Home Affairs Section, House of Commons Library) pp.1-16.

Stoller N, 2003, "Space, Place and Movement as Aspects of Health Care in Three Women's Prisons' Social Science and Medicine 56 (11), 2263-2275. 
Sugimori Y, Kusunoki K, Cho F, Uchikawa S, 1977, "Toyota Production System and Kanban System: Materialization of Just-in-Time and Respect-for-Human System" International Journal of Production Research 15(6), 553-564.

Sykes G, 1958, The Society of Captives (Princeton, N J, Princeton University Press).

Urry J, 2004, "The 'System' of Automobility" Theory Culture and Society 21 (4/5), 25-39.

Vaz P, Bruno F, 2003, "Types of Self-Surveillance: From Abnormality to Individuals 'at Risk"” Surveillance and Society 1(3), 272-291.

Wacquant L, 2010, "Crafting the Neoliberal State: Workfare, Prisonfare and Social Insecurity" Sociological Forum 25 (2) 197-220.

Wacquant L, 2009, Punishing the Poor: The Neoliberal Government of Social Insecurity (Durham, NC: Duke University Press)

Wacquant L, 2001, "Deadly Symbiosis: When Ghetto and Prison Meet and Mesh" Punishment and Society 3(1), 95-134.

Weber M, 1978 Economy and Society, vols 1 and 2, Eds G Roth and C Wittich (Berkley, University of California Press)

Woolredge J, 1991, "Identifying Possible Sources of Inmate Crowding in US Jails," Journal of Quantitative Criminology 7 (4): 373-386. 